\title{
EGYES LESZAKADÓ TÁRSADALMI CSOPORTOK MODERNIZÁCIÓS TÖREKVÉSEI
}

\author{
(The Modernisation Endeavour of Certain Social \\ Disadvantaged Groups)
}

\section{SZARVÁK TIBOR}

Már-már közhelynek számít, hogy a XX. század utolsó évtizedében a magyar társadalom elodázhatatlan lehetőség előtt áll, mert résztvevője lehet egy szorosabb európai integrációs folyamatnak. Ahhoz, hogy ne legyenek újabb „elkésődéssel” jellemezhető fejezetei az ország modernizációjának, elengedhetetlen a társadalom adaptációs, valamint innovációs stratégiáinak teljesebb vizsgálata.

Jelen munka az újitás különböző szerepkészletével hagyományosan kevésbé bíró, az objektív-relatív depriváció összetett elemeivel (alacsony jövedelem, alacsony iskolai végzettség, rosszul felszerelt, egészségtelen vagy szükös lakáskörülmények stb.) jellemezhető, a globalizációs folyamatoktól elmaradó, rurális térségekben élő népesség felzárkózási és fejlődési (adaptáció-innováció) esélyeit kutatja az ország három, a területi egyenlőtlenség különböző dimenzióival jellemezhető megyéjében (Békés, Hajdú-Bihar, Jász-Nagykun-Szolnok) ${ }^{1}$.

Az elemzés mintavételi keretét egy, a Népjóléti Minisztérium által hat éve indított szociális földprogram, a programba került családok (és háttérként a programban részt vevő települések) listája adja. Regionális hatásvizsgálatunkban képet kapunk arról, hogy a kérdezettek foglalkozási státusa miként alakult az elmúlt 18 évben, milyenek a családok szociológiai vonatkozásai, illetve kutatjuk azt is, hogy milyen életkörülményekkel és törekvésekkel jellemezhetők a fenti szociális transzfert igénybevevök.

\section{A minta jellemzői, a vizsgálat területei}

$\mathrm{Az}$ adatfelvétel módszereként a véletlen kezdöpontú szisztematikus mintavételt választottuk. A lekérdezést kérdezöbiztosokkal végeztük. A három megyében összesen 907 család/kedvezményezett vett részt a földprogramban. 117 fös mintánk (52\% nő, 48\% férfi) - az alapsokaság 13\%-a - véleményünk szerint megfelelően reprezentálja az érdekelt alapsokaságot.

A települési mintánk Békés megyében 12 településböl (Békés, Battonya, Elek, Gádoros, Kisdombegyház, Méhkerék, Mezőgyán, Mezőkovácsháza, Okány, Vésztỏ, Zsadány, Újszalonta), Hajdú-Biharban szintén 12 településből (Bihardancsháza, Egyek, Hajdúszovát, Körösszakál, Körösszegapáti, Komádi, Létavértes, Magyarhomorog, Mezőpeterd, Mezősas, Nagyrábé, Vámospércs), Jász-Nagykun-Szolnok megyében pedig 7 településböl (Cibakháza, Mesterszállás, Öcsöd, Tiszabö, 
Tiszabura, Tiszasas, Tiszaug) állt. A centrum-periféria elméletből következỏ vidékdefiníciók alapján kutatási területünket a „vidék” jellemzővel (azt a települést tekintjuk vidékinek, amely városi státusszal nem rendelkezik, vagy rendelkezik ugyan városi ranggal, de lakónépessége 10 ezer fönél kevesebb) (Magyarország Vidékfejlesztési... 1997) kategorizálhatjuk. A vizsgálatunkba került településekről látható, hogy a szociális földprogram elsősorban az agrár-munkanélküliség, a rurális térségek és a válságban lévő ipari központok ingázási feszültségeit csökkentheti. Érdemes megemlítenünk azt, hogy vizsgálatunkban a szociális földprogram településeinek kétharmada a határ mentén helyezkedik el.

Elemzésünkben egyrészt a területi/megyei jellemzőket, másrészt - mivel a szociális földprogram alanyai között a romák nagy számban megtalálhatók - az etnikai (roma, nem roma) dimenziókat is figyelemmel kísértük. Kemény István 1971-es kutatásához hasonlóan ,azokat a személyeket soroltuk a romákhoz, akiket a nem roma környezet annak tart" (Kemény-Havas 1996, 352). Ez alapján alkottuk meg elemzésünk egyik keretét, az identifikációs változót. Mintánk egyharmadát alkotják a cigány megkérdezettek.

\section{A szociálpolitika megújítása: szociális földprogram}

A társadalmi-gazdasági folyamatokban végbemenő változások a lakossági jövedelmek igen jelentös differenciálódását, a reáljövedelem tartós csökkenését és a szociális szükségletek robbanásszerü növekedését idézték elö. Mindez fokozottan jelentkezett a halmozottan hátrányos helyzetü polgárok, családok körében. A szociálpolitika hagyományos - 1990 előtt kialakult - formái nem képesek a piacgazdaság körülményei között kezelni a szegénység és az egyenlőtlenség problémáit. Különösen érzéketlenek ezek az eszközök a térségi, regionális léptékủ problémákra (Országos Területfejlesztési... 1997). Ahogyan növekedett a munkanélküliség, és erősödött a munkaerő-piaci marginalizáció és szegmentáció, úgy haladt előre a szociális védelemre való univerzális jogosultság törvényi és rejtett felmondása (Standing 1993). Az univerzalitás eszményétöl szabaduló szociálpolitika átalakulási folyamata - bizonyos szempontokból a két világháború közötti időszak eredményeit, valamint a jóléti állam lebontásának különböző intézkedéseit is felhasználva - az aktív eszközök alkalmazásával felgyorsult.

A szociális földprogram, mint szociális transzfer 1940. június 19-hez, KeresztesFischer Ferenc belügyminiszter Országos Nép és Családvédelmi Alapról szóló törvényjavaslatához kapcsolódik. Ezután indította meg Esztergár Lajos a „Vármegyei Közjóléti Szövetkezet Mátészalka" elnevezésủ kísérletét. A tevékenység fő elve az volt, hogy segélyezéssel, szegénypolitikával nem lehet hatékonyan javítani a rászorulók helyzetén, ezért a szociális feladatok megoldásának formáját a gazdasági szférára bízta.

A szociális földprogram kilencvenes évekbeli felújítása ebben a mikro-mezomakro problémákat/hátrányokat komplexen kezelő elképzelésben gyökerezik. A földprogram a falvakban, agrártérségekben élö, szociálisan hátrányos helyzetủ családok, tartós munkanélküliek életminőségének javitására, a meglévö munkaerő 
tartós munkanélküliek életminőségének javítására, a meglévő munkaerö mezőgazdasági tevékenységbe történö bevonására szolgál. A projekt lényege a természetbeni támogatás és szolgáltatás.

\section{A szociális földprogram modernizációs hipotézisei}

$\mathrm{Az}$ alkalmazás, átvétel (adaptáció), valamint az újítás (innováció) elemeinek vizsgálatához elengedhetetlen a szociális földprogram modernizációs hipotéziseinek (Serafin 1997) felsorolása.

- A lokális szociálpolitika új, rugalmas, átlátható gazdasági elemmel bỏvül. Túlélési és hátrányos helyzetböl történö kivezetési programként egyaránt használható.

- Produktív jellege miatt a támogatottság morálisan elfogadhatóbb, mint a segélyezés, mind az egyén, mind a helyi társadalom számára. Az aktivitás csökkenti a tartós munkanélküliség okozta mentális problémákat. A program frissen tart, vagy megerösít készségeket, motivációkat, ami növeli az esélyt az előnyösebb helyzetbe jutásra.

- Javul a helyi társadalmi integráció, kapcsolatok, szerveződések jönnek létre. Erösödik a helyi gazdasági és társadalmi autonómia. Az együtt munkálkodás miatt növekszik a tolerancia a társadalmi rétegek között ( $H V G$ 1997).

- Csökken az elvándorlási kényszer ereje.

- Kihasználatlan emberi, tárgyi és természeti erőforrások kerülnek bevonásra a szociális rendszerbe, valamint egy általános értékteremtő folyamatba.

- Javul a vagyonbiztonság, különösen a mezei lopások száma csökken ${ }^{3}$.

\section{A szociális földprogramban résztvevők}

\section{Az életmód jellemzöi}

Ebben a fejezetben a hasonló társadalmi körülmények között nagy szabadságfokkal megválasztott tevékenységeket, mint az adaptáció és az innováció gyökerét vizsgáljuk. Dimenzióink között szerepelnek az életvilág ${ }^{4}$ jellemzöi: a közvetlen környezet, a háztartás tárgyai, a ,javak”, a kulturális töke elemei, a munka, az innováció és az értékek elemzése.

A megkérdezettek kora (a szociális földprogram korábban közölt jellemzöi miatt) az innovációs folyamat outputja szempontjából fontos. A többséget a 25-50 év közöttiek jelentik. 51 év felett leginkább Hajdú-Biharban vesznek részt a programban, 24 év alatt pedig Békésben. Egy másik összevetésböl az derül ki, hogy ez a 24 év alatti, fiatal felnőtt generáció leginkább roma (a 66 év felettiek pedig magyarok). A romák többsége 25-35 év közötti.

A családok és lakóépületük komfortfokozatára, infrastrukturális ellátottságára, felszereltségére vonatkozó kérdéseink elemzésekor érdemesebb a válaszokat a 
„nincs” kategória felöl megközelíteni (Szoboszlai 1999), ezért a kilencvenes évek különbözö fejlesztései gyakorlatilag egyfajta életmódváltást, életminőség-javulást a többség számára nem tudnak indukálni. Ez a társadalmi tény, mivel egy többségében hátrányos életvilágban élő rétegröl van szó, tartósítja és erősíti a szegmentációt. A hiányokat részleteiben nézve azt látjuk, hogy a háztartások villannyal való felszereltsége a legkevesebb helyen nem valósult meg, ezt követi a vezetékes vízzel való ellátottság, viszont - valószínüleg a kilencvenes évek gázprogramja következtében a mintának csak majdnem fele - nem rendelkezik vezetékes gázzal (1. ábra).

\section{1. ÁBRA}

Infrastrukturális javak az identifikációs változó tükrében (\%)

(Infrastructures According to the Identification Variable)

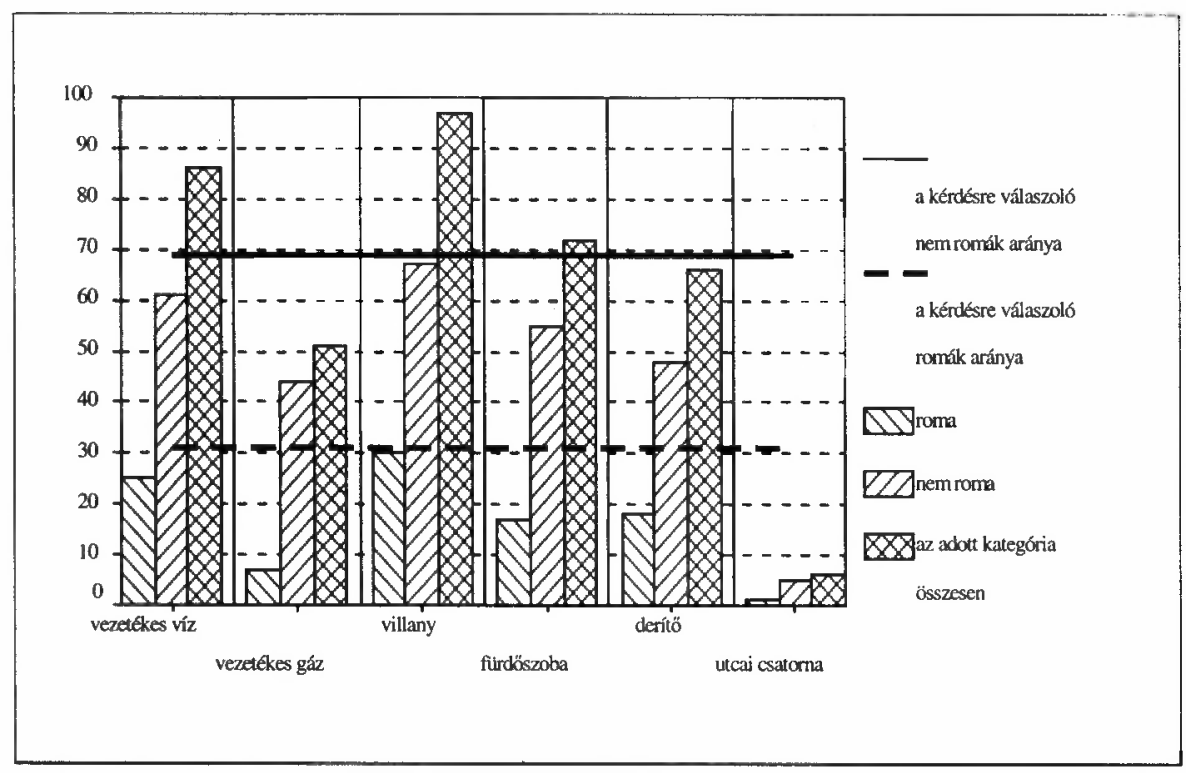

Forrás: MTA RKK ATI Szolnoki Társadalomkutató Csoport 1999.

$\mathrm{Az}$ infrastrukturális viszonyok területi vetületében két tényező emelkedik ki. Az egyik Hajdú-Bihar megye hátránya, ahol a megkérdezettek többségének lakásában nincs vezetékes gáz, a másik Békés megye relatív elsősége a csatornázottságban (e megyei mintában találtuk a legtöbb utcai csatlakozású csatornával rendelkező földprogramban résztvevót).

A fogyasztási javak területi vonzatában elmondható, hogy a legtöbb telefonnal és keleti illetve nyugati gépkocsival a Jász-Nagykun-Szolnok megyei kérdezettek rendelkeznek. A társadalom különbözö rétegeiben meglévő presztízsfogyasztási elemet (a státust szimbolizáló tárgyak a fölfelé törekvést szimbolizálják) ( $S$. Nagy 1997) mintánkban a videó töltötte be. Roma és nem roma megkérdezetteink körében ez az a fogyasztási cikk, amelyik a „legtöbb” háztartásban (leginkább a JászNagykun-Szolnok megyei megkérdezettek körében ${ }^{5}$ ) megtalálható. 
Összefoglalva: adataink az életmódjavító fogyasztói, polgári és infrastrukturális javak hiányát mutatják. Ez a tény megnehezíti a személyben jelentkező adaptációt, valamint az innovációt; az olyan attitüdionális, információs és viselkedési jellemzőknek a kialakulását, amelyek ösztönzik, illetve arra képesítik az egyént, hogy bekapcsolódjon a gazdaság és a makro-társadalom globális fejlődési folyamataiba (információs kihívások) (Varga 1968) (2. ábra).

\section{2. ÁBRA}

Fogyasztói javak az identifikációs változó tükrében (\%) (Consumer Goods According to the Identification Variable)

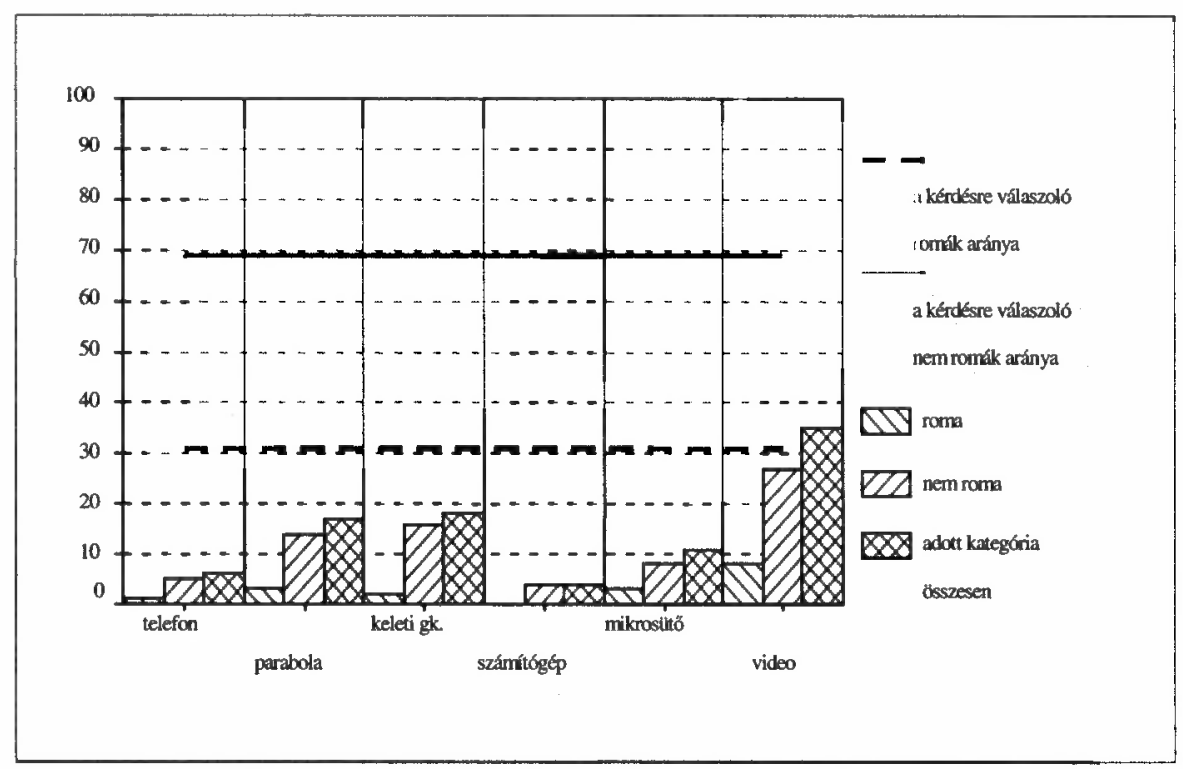

Forrás: MTA RKK ATI Szolnoki Társadalomkutató Csoport 1999.

\section{A kulturális tỏke gyökerei}

Az iskolai végzettség a társadalmi pozíció reprodukciójában jelentős kapcsolati és kulturális tőke mérhetőségének egyik fajtája, fontos modernizációs aspektus. Kutatásunk a kulturális/iskolai mobilitás csatornája felől közelített a kérdéshez. A változások trendje a földprogram aktív generációjának (a háztartásokban élö aktív korúak átlaga 2-3 fö között van) innovációs-adaptációs készenléti állapotára is választ ad. A roma édesapák többsége $1-4$, illetve 5-8 osztályt végzett, a nem romák esetében 5-8 osztályt végzett szülöt regisztrálhattunk leginkább, de jellemző a szakmunkás-bizonyítvány is. A fentiek megyei bontása annyiban árnyalja a képet, hogy Békésben az 1-4 osztályt végzettek, Hajdú-Biharban pedig a szakmunkások egynegyede él. A roma megkérdezettek körében a saját iskolai végzettség terén 
még az 5-8 osztály a domináns, de a $25 \%$-os szakmunkás arány már komoly elörelépést jelent ${ }^{6}$.

A mobilitási kereszttáblákból kiolvasható, hogy a semmilyen iskolával vagy 1-4 osztállyal rendelkező apák gyermekei elvégzik az 5-8 osztály valamelyikét. A 8 általánost befejezett megkérdezetteknek több mint felénél azt tapasztaltuk, hogy az édes/nevelỏ apák is hasonló végzettséggel rendelkeztek. A szakmunkás végzettségủ megkérdezettek harmada 5-8 osztályt végzett apával, közel 40\%-uk pedig hasonló végzettségü szülővel „,bír”.

A mobilitási tükörből látható, hogy az apa végzettségének reprodukciója ma már nem elegendỏ, nem jelent szilárd innovációs alapot. Az okok részben az objektívrelativ deprivációs tényezőkre (a megkérdezettek több mint fele jelzett valamilyen egyéni vagy társadalmi továbbtanulást gátló tényezőt), valamint azokra a globális folyamatokra vezethetök vissza, amelyekben egy tradicionálisan alacsony végzettséggel rendelkező réteg szükségképpen marginalizálódik, az innovációs trendhez kapcsolódni önerőből nem tud. Az adaptációs folyamatok is csak azok számára lesznek sikeresek (változtatás-előkészítők), akik rendelkeznek bizonyos kapcsolódási pontokkal, korábbi fogódzókkal. Azonban a régi struktúrák, az objektív-relatív deprivációs tényezök miatt a kiút, a kivezetés iránya determinált, tradicionális jellegü.

\section{Foglalkoztatási viszonyok}

A család, a környezet, a kortárs csoport és az iskola mellett a munka világa az, amelynek fontos szerepe van az ember szocializációjában. A foglalkozási szerep az egyén identitásának lényeges eleme. Különösen jelentös hatása van az utóbbinak a halmozott hátrányokkal küzdö réteg esetében, mert a munkahely gyakorlatilag az utolsó olyan folyamatos létező teret jelenti számukra, ahol a különféle innovációs stratégiák megismerésével és elfogadásával az egyéni élethelyzet gazdagodhat.

Az első munkaviszony éve mintánkban dominánsan az 1971-1980 közötti évtizedre esett. Ez a megállapítás elsősorban a nem roma népességre igaz. A többségében fiatalabb roma megkérdezettek ugyanis leginkább a nyolcvanas években álltak munkába.

A minta túlnyomó többsége abban a korszakban lépett be első munkahelyére, amikor a hivatalos ideológia a rendszer alapvetö vivmányának minösítette a teljes foglalkoztatást, amely garantált jogként rögzödött a kollektiv tudatban, valamint ténylegesen az Alkotmányban. A teljes foglalkoztatást a foglakoztatás-politika elvei és gyakorlati konvenciói, valamint a klasszikus szocialista rendszer egész müködési mechanizmusa, mindenek elött a krónikusan újratermelődő - föként szakmunkásokból, közép- és felsőfokú végzettséggel rendelkezőkböl - munkaeröhiány biztosította (Kornai 1993). A munkaerőtöbblet túlnyomó része ezért szakképzetlen munkaeröbỏl állt.

A korábban tárgyalt tényezők bizonyították azt, hogy mintánk, a szociális földprogramban részt vevő családok hátránya több évtizedes, halmozott. Nézzük, miként tükröződik ez a foglalkoztatás dimenzióiban. Elsöként az apa foglalkozását 
vesszük sorra. Az apák egyharmada mezőgazdasági szakképzetlenként dolgozott a kérdezett 14 éves korában. (Az 5-8 osztályt végzett apák közül gyakorlatilag mindenki a mezőgazdaságban dolgozott.) Az ipari betanított apák aránya 15\%. (Az 5-8 osztályt végzett apák közül közel $20 \%$ lett ipari foglalkoztatott.) A vezetö, értelmiségi, szellemi dolgozó, közvetlen termelésirányító kategória a minta egészének 4\%-át alkotja. A roma almintában jellemzőbb a mezőgazdasági szakképzetlenek, valamint az ipari betanított munkások magas aránya. Az ipari betanított munkás apák leginkább Hajdú-Bihar megyében, a mezőgazdasági szakképzetlenek pedig JászNagykun-Szolnok megyében dolgoztak.

\section{Életutak, stratégiák}

A foglalkozási mobilitás kereszttábláját figyelve látható, hogy 1980-1985 között a mezőgazdasági szakképzetlen apák gyermekei közül minden tizedik reprodukálta ezt a státust. Negyedük gazdasági alrendszert váltott, ipari betanított dolgozó lett, tizedük a képzettségi lépcsőn is előbbre haladt, mert ipari szakképzettként dolgozott. Változásról még a szolgáltatásban-kereskedelemben dolgozó apák gyermekei körében beszélhetünk, akik 60\%-a szellemi dolgozó lett.

A kérdezettek foglalkozási mobilitásának vizsgálatakor egy fontos modernizációs mutatóhoz, a foglalkozási struktúra piaci presztízséhez (rentábilis/nem rentábilis) jutunk. „Történelmi visszapillantónk” első időpontja az 1980-1985 közötti öt év. Akik ebben a korszakban szellemi, illetve szolgáltatási/kereskedelmi dolgozók voltak, maradtak a következő 6 évben is az indító pályán. Nagyobb léptékü összehasonlításban jól látszanak a tradicionálisan alacsony iskolai végzettséggel és foglalkozási pozícióval rendelkezők lehetőségei. Akik a nyolcvanas évek elején még mezőgazdasági, illetve ipari szakképzetlenek, 1993-1997 között vagy nyugdíjasok, vagy munkanélküliek voltak.

A struktúraváltás másik jellemzöje a területi mobilitás. Mi ezt a munkahelyek tekintetében vizsgáltuk. Azok, akik lakóhelyükön dolgoztak 1980-1985 között, közel 100\%-ban ugyanazon a településen folytatták a munkát 1986-1992 között is. A megye valamely településén munkát találók több mint fele tovább ingázott, közel $40 \%$ viszont lakóhelyén dolgozott tovább. A roma/nem roma változó figyelembevételekor azt látjuk, hogy a roma megkérdezettek 40\%-a 1980-1985 között jelenlegi lakóhelyén dolgozott. Jelentös közöttük az ipari szak- illetve betanított munkás, valamint a mezőgazdasági szakképzetlen munkások aránya. A megye más településén harmaduk, budapesti munkahelyen ekkor közel negyedük fordult meg. A korábban említett munkaerőhiány teremtette azt a helyzetet, hogy a szocialista nagyipar egyes ágazatainak szuiksége volt az olcsó, hagyományosan kvalifikálatlan munkaerőre. Ez körükben modernizációs folyamatokat indított el. A romák a szocialista munkahelyen „belülre” kerültek, egyszeriben alanyaivá váltak mindannak, ami a szocialista foglalkoztatottakra vonatkozott (Szalai 1998). A stabilitás azonban nem volt tartós, mert 1986-1992 között a megkérdezett roma népesség közül már csak egy fő dolgozott a fôvárosban, negyedük a megye valamely településén és kéthar- 
maduk jelenlegi lakóhelyén. Az ingázások véget értek. 1993-1997 között már a roma alminta csaknem teljesen a jelenlegi lakóhelyéhez köti foglakoztatási státusát. A roma megkérdezettek munkavállalásában csökken az ipari munkahelyek száma, megnỏ viszont a lokális adottság, a válságban lévő mezőgazdasági foglalkoztatottság szerepe. Ebben a korszakban a roma alminta közel fele (a nem romák egyharmada $^{7}$ ) volt dominánsan munkanélküli. A munkanélküliség gócpontjainak számító kistérségeket, vizsgálatunk domináns helyszíneit az ingázást (mint életformát) követelő munkahelyek felszámolása többszörösen érintette. A kárpótlás bumeráng hatása és az agrárválság tovább növelte a munkanélküliséget. A kvalifikálatlan munkát igénylỏ munkahelyek elsöként szüntek meg.

A mobilitási csatornák fokozatos záródásával vizsgált népességünk körében befejeződött/megszakadt az a felemelkedés, a modernizáció - esetünkben ez a proletarizálódás folyamatával jellemezhető (Kemény-Havas 1996) -, amely a stabil munkahely adta lehetőséget kihasználva, a vagyoni gyarapodás eszközével, az életmód és a szokások változásával vélte a hátrányokat csökkenteni.

\section{Krízis: vannak-e kitörési pontok?}

A munkanélküliség az egyéni élethelyzet bizonytalanságát - egyrészt a szociális kapcsolatokban, egzisztenciális helyzetben, másrészt a folyamatos teljesítmény elmaradása kapcsán - növelve az adaptív folyamatok ellen hat. Mindez a tartós munkanélkülieknél fokozottan jelentkezik. Korábbi jellemzók alapján elmondható, hogy a szociális földprogramba került családok munkanélküli megkérdezetteinél a munkaerőpiacon manapság nélkülözhetetlen készségek, képességek vagy eleve hiányoztak, vagy a munkanélküliség ideje alatt sérültek. Integrációjuk az esetek többségében már inkább a szociális, mint a munkaügyi alrendszer feladata (lenne) (Diebel 1996).

A szociális földprogramban részt vevó roma megkérdezettek háromnegyede 10 hónapnál régebben munkanélküli (ez az arány a munkanélküli, nem roma alminta esetében 91\%). A területi megoszlásból azt látjuk, hogy két megye (Békés, JászNagykun-Szolnok) tartós munkanélkülieinek 24 hónap az elválasztó idő, 84 hónapja ( 7 éve) a hajdú-bihari kérdezettek negyede van munka nélkül. Érdemes megemlíteni, hogy azok, akik 1980-1985 között a fövárosban dolgoztak, 72 hónapja nem találnak munkát. Hazajöttek, újra elhelyezkedni nem volt lehetöségük.

A tartósság aggasztó hatásai mellett a krízist növeli, ha a háztartásban nincs más aktív személy. Mintánkban azok, akik 1993-1997 között leginkább munkanélküliek voltak, közel fele arányban hasonló státusú házastárssal rendelkeznek. Elgondolásunk szerint a két nem keresős háztartás-típusban hatványozottan jelentkezik a földprogram szociális hatása, amely egy családot tarthat frissen, vagy erósitheti meg a munkához, rendszeres foglakoztatáshoz kapcsolódó készségeit, motivációit, növelve ezáltal az adaptáció/innováció esélyeit. Az adatfeldolgozásból kitúnik, hogy a 2-5 fös családok nagy többségében a szociális földprogramban két személy dolgozik. 
Itt érdemes idézni a program személyi networkjének, hálózatának mutatóit. A korábban becsült családszám mellett a bevonható humán erőforrásokra a családnagyság és a földprogramban dolgozók száma jelent egzakt mutatót. Vizsgálatunkban egy fổtől 14 föig terjed a háztartásban együtt élök száma. Jellegzetes családnagyság mindhárom megyében az öt fős család. A romák körében is leginkább a 4-6 fös család a jellemző, de megtalálhatók a „hagyományos szélsőértékek” is, a 12-nél több tagot számláló nagy famíliák. A földprogramban már föként az aktív korúak dolgoznak, de Békésben és Hajdú-Biharban előfordult, hogy a nagyobb haszon vagy a települési munkanélküliségi ráta magas aránya miatt a tágabb családot (5 fö) is bevonták a munkába, az értékteremtő folyamatba.

$\mathrm{Az}$ értékek tartósságára ad választ az a kérdés, amelyik a munkanélküliség és a kényszerüségböl feladott tervek kapcsolatát vizsgálja. Ebböl kiderül, hogy a minta egyformán feladta håzának további építését, felújítását, mind a lakás kényelmi szintjének emelését. A gyermekek taníttatásáról, mint kulturális, a kiemelkedést elősegítő tőkéröl a megkérdezettek több mint kétharmada nem mond le.

Fontos területi szegregációra utaló tényező lehet abban, hogy a minta egytizede a munkanélküliség miatt lemondott arról a tervéröl, hogy elköltözzön lakóhelyéröl. (A roma kérdezettek körében ez az arány közel $85 \%$.) Itt kell megemlítenünk azt, hogy a modernizációs hipotézisek között szereplő „,csökken az elvándorlási kényszer” kategóriáját nem látjuk bizonyítottnak. A „füstbement terv” hátteréhez tartozó tény az, hogy akik lakóhelyváltást terveztek 1980-1985 között a fővárosban, 19861992 között leginkább mostani lakóhelyükön dolgoztak. 1993-1997 között viszont 50\%-uk már munkanélküli volt.

A lokalitás adaptív/innovatív hatása a mobilitási tényezők mellett a földprogrammal foglalkozó szervezetek, összejövetelek kapcsán is mérhető. A megkérdezettek negyede jelezte azt, hogy már létezik ilyen típusú szerveződés. A legtöbb ilyen összejövetelt Jász-Nagykun-Szolnok megyében regisztráltuk.

Kérdőívünkben közvetlen, az anyagi viszonyokra vonatkozó kérdés nem szerepelt, a szociális transzferekben való részesültségből - korábban pedig a fogyasztási és infrastrukturális javakból - következtethettünk a materiális háttérre. Általánosan elmondható, hogy a szociális segélyezés az utolsó eleme annak a biztonsági hálónak, amely az embereket a szegénységtöl védi, illetve védené. Az 1997. novembertöl adható gyermekvédelmi támogatásban a többség még nem részesül. A megyék közül ezt a fajta támogatást leginkább Hajdú-Biharban folyósítják a megkérdezetteknek. A rendszeres szociális segély a minta egészében nem jellemező. A lakásfenntartási támogatást csak öt - nem roma - kérdezettnek utalják az érintett önkormányzatok. A szociális földprogrammal kapcsolatban a minta többsége tudja, hogy ez nem pénzbeli szociális ellátás. Ápolási dijban négy nem roma és kettő roma megkérdezett részesül. Az átmeneti segélyt kapók több mint fele a roma almintába tartozik. (Az átmeneti segély osztása leginkább Békés és Hajdú-Bihar megyére jellemzö.) A közgyógyellátás is inkább a roma kérdezetteknek ,jár”. A munkanélküliek jövedelempótló támogatásában az összes megkérdezett egyharmada 
részesül. Az átlag mögötti jelentős területi különbség, hogy Jász-Nagykun-Szolnok megyében és Hajdú-Biharban harmaduk részesül e szociális transzferből, ugyanakkor Békés megyében csak a kérdezettek egytizede. A családsegítéssel, mint személyre szabott segítséggel a minta egy nem roma család kivételével még nem találkozott. A szociális transzferek hasznossági sorrendjét a szociális földprogram vezeti, s a családsegítés zárja.

\section{TÁBLÁZAT}

Hogyan értékeli a szociális transzfereket hasznosság szerint?* (How do You Assess the Usefulness of Social Transfers?)

\begin{tabular}{lc}
\hline Szociális földprogram & 79 \\
Gyermeknevelési és gyermekvédelmi támogatás & 73 \\
Közgyógyellátás & 71 \\
Étkeztetés & 71 \\
Rendszeres szociális segély & 67 \\
Munkanélküliek jövedelempótló támogatása & 67 \\
Átmeneti segély & 67 \\
Köztemetés & 66 \\
Ápolási díj & 63 \\
Házi segítségnyújtás & 63 \\
Lakásfenntartási támogatás & 62 \\
Családsegítés & 62 \\
\hline *100 fokozatú skála átlagpontjai; eredeti értékek: 1=felesleges, 2=inkább felesleges, 3=is-is, \\
4=inkább hasznos, 5=teljes mértékben hasznos. \\
A loo fokú skála akkor lenne 0, ha mindenki feleslegesnek, és akkor lenne 100, ha mindenki \\
teljes mértékben hasznosnak értékelné az adott szociális transzfert. \\
Forrás: MTA RKK ATI Szolnoki Társadalomkutató Csoport 1999.
\end{tabular}

Fontos elmondani, hogy a munkanélküliség idején leginkább a közhasznú programok foglalkoztatták a megkérdezetteket. A szürke/fekete gazdaságba tartozó alkalmi munkát a válaszadók majdnem fele (a roma alminta kétharmada) jelölte meg pénzkereseti forrásként.

$\mathrm{Az}$ anyagi tartalékok másik dimenziója az, hogy a kérdezettek milyen saját forrással járulnak hozzá a földprogram sikeréhez. A válaszokból kiderült, hogy a megkérdezettek a sikerhez leginkább termelési eszközzel, valamint pénzzel járultak hozzá. Itt azonban hatalmas az eltérés a roma és a nem roma minta között, mert az utóbbiak majdnem $90 \%$-ban tudják így segíteni a programot.

Az anyagi javak között érték és életmód is a föld. Utóbbit kérdöívünk egy nagyobb területre, valamint a házhoz csatlakozó kertre (kisháztáji) bontotta. A minta többségének van ház körüli kertje..Fontos adaptációs kategória az, ha a kertjét nem hagyja parlagon az ember. Mintánkban csak 8 fö jelezte azt, hogy kertjét nem müveli. A család vagyonát, megélhetési lehetöségeit növeli, ha nemcsak kertje van, hanem esetenként nagyobb (jobb minőségü) földje is. A romák egytizede, a nem romák közel fele rendelkezik ilyen tulajdonnal. A föld nagyságát tekintve az mondható el, hogy a romák 5 hektár alatti területtel bírnak, a nem romák fele rendelkezik 
hasonló nagyságú mủvelhető területtel. Néhányan azonban a helyi társadalom tehetősebb rétegei közé tartoznak, mert 6 és 41 hektár közé eső földterülettel rendelkeznek. A földnagyság területi bontásából képet kapunk arról, hogy az egyes önkormányzatok (mint a vizsgált szociális transzfer egyetlen szürỏje) hogyan kezelik a földprogramba kerülés kritériumait. A mintába került szociális földprogramban résztvevők körében hat hektárnál nagyobb birtokok csak Hajdú-Bihar és JászNagykun-Szolnok megyében találhatók.

Értelmezésünk szerint hasonló (adaptív/innovatív) vonatkozása, kultúrája van a haszonállat tartásának is. A nem roma megkérdezettek háztartásában leginkább sertést vagy baromfit találunk. A roma életvitelủ válaszadóink közel 40\%-ban tartanak - hasonló fajtájú - állatot. Náluk azonban szarvasmarha, valamint juh egyáltalán nincs.

A kapcsolatok, a személyes kooperáció vetủlete, hogy földprogramos problémák esetén kihez fordulnak segítségért a kérdezettek. Összességében az mondható el, hogy a megkérdezettek leginkább a település valamely választott testülete képviselöjéhez fordulnának, bár figyelemreméltó, hogy probléma esetén minden hetedik család nem tud kihez fordulni. A szervezett segítség hiánya különösen Hajdú-Bihar megyében kimagasló, hiszen ott a résztvevők közel 40\%-a tanácstalan.

A fenti kapcsolati pontokból levonható fontos összefüggés, hogy egy tartósan mélyponton lévő réteg innovációs potenciáljának a növekedéséhez és tágabban a település megtartó erejének az emeléséhez a kulcs a helyi hatalom modernizációs, innovációs készségében rejlik. A helyi vezetésnek a társadalom különbözö alrendszerei irányában tett fejlesztési, polgárosító elképzeléseiben egy civil társadalmi jellemzőt, a „képessé tevés” technikáját kell(ene) elsajátítani. Tudjuk, hogy ez a mủködési kód nem a közigazgatás jelenlegi sajátossága, de alkalmazása egyrészt a lokalitás eröinek, a polgári kezdeményezések meggyökeresedéséhez, az önkormányzatiság ethoszához, másrészt a célcsoport hátrányos helyzetébỏl való elmozdulásához vezethet.

\section{Földprogram: vissza a munka világába}

A krízisből való kilépés stratégiáinak fontos eleme a munka és a hozzá kapcsolható egyéni értékek. A kérdőívben szereplö „3 kívánság” itemek elemzése után azt tapasztaltuk, hogy a megkérdezettek több mint egyharmadánál elsősorban az életszínvonal emelkedéséhez kapcsolódó - anyagi vonzatú - kívánság a az elsődleges választás. Szignifikáns különbség az általános, magasabb rendủ értékekkel definiált kívánságoknál, a munkához kapcsolódó értékeknél és az egészséggel kapcsolatos kívánságoknál mutatkozik a nem roma megkérdezettek javára. $\mathrm{Az}$ ismeretekhez kötődő értékeket a minta alig 3\%-a tartotta elsőként fontosnak.

A nemi szerepekhez kapcsolódva néhány eltérésre hívjuk fel a figyelmet. Az egyik az egészség - a nők kétharmada választotta -, valamint a munkával kapcsolatos preferenciák, amelyet a megkérdezett nők közel 70\%-ban, a férfiak pedig egyharmad arányban jelöltek meg elsődlegesen. Fordított megoszlást az anyagi 
javak esetén tapasztaltunk. Ezt az értéket a férfiak kétharmada választotta. Az ismereteket, a tudást viszont egyformán fontosnak ítélte mindkét nem.

A életkor és az első kívánság keresztábrájából az olvasható ki, hogy a vizsgálatban szereplö legfiatalabb kohorsznál az anyagi természetü kívánságok a dominánsak, az ismeretek, a kulturális tőke a 25-35 éveseknél a legfontosabbak, de ennél a korosztálynál nem elhanyagolhatóak az anyagi természetủ, a munkához, a lakhelyhez, valamint a magasabb rendü értékekhez füződö preferenciák sem. A 36-65 éves almintánál az anyagi kívánságok a legfontosabbak, a 41-50 közötti korosztálynál azonban a munkához és az egészséghez kapcsolódó értékek - talán, mert az egyik leginkább veszélyeztetett korcsoportról van szó - is jelentösek. A 66 év felettieknél az általános, magasabb rendủ értékpreferenciák vezetik a „listát”.

A modernizációs folyamatok tartóssága szempontjából fontos, egyfajta életmódmeghatározó az, hogy az érintettek miként értesülnek/értesülhetnek leginkább a körülményeiket befolyásoló projektekről. A hajdú-bihari megkérdezettek közel 20\%-a szórólapok, plakátok révén tájékozódott a programról. (A 3 megyét érintő vizsgálat során kiderültt, hogy ez a módszer csak Hajdú-Biharban volt általános.) Hasonlóan elhanyagolható a szerepe a helyi és a megyei médiának. A lokális írott sajtóból egyedül a Jász-Nagykun-Szolnok megyei alminta értesült a földprogramról. A falugyúlés, közmeghallgatás is csak ebben a megyében jelentős.

Az identifikációs változó alapján is látható, hogy az információk forrása leginkább egy testület vagy egy személy (3. ábra). Bár a média szerepe nem jelentős, a szociális földprogram sikeressége (a „Belekezdene-e újra?” kérdésre adott válaszok alapján) ęrősebb ott, ahol a megkérdezettek ilyen jellegü információs forrást vettek igénybe a jelentkezéskor.

\section{3. ÁBRA}

Kommunikációs csatornák az identifikációs változó tükrében (\%)

(Communication Channels According to the Identification Variable)

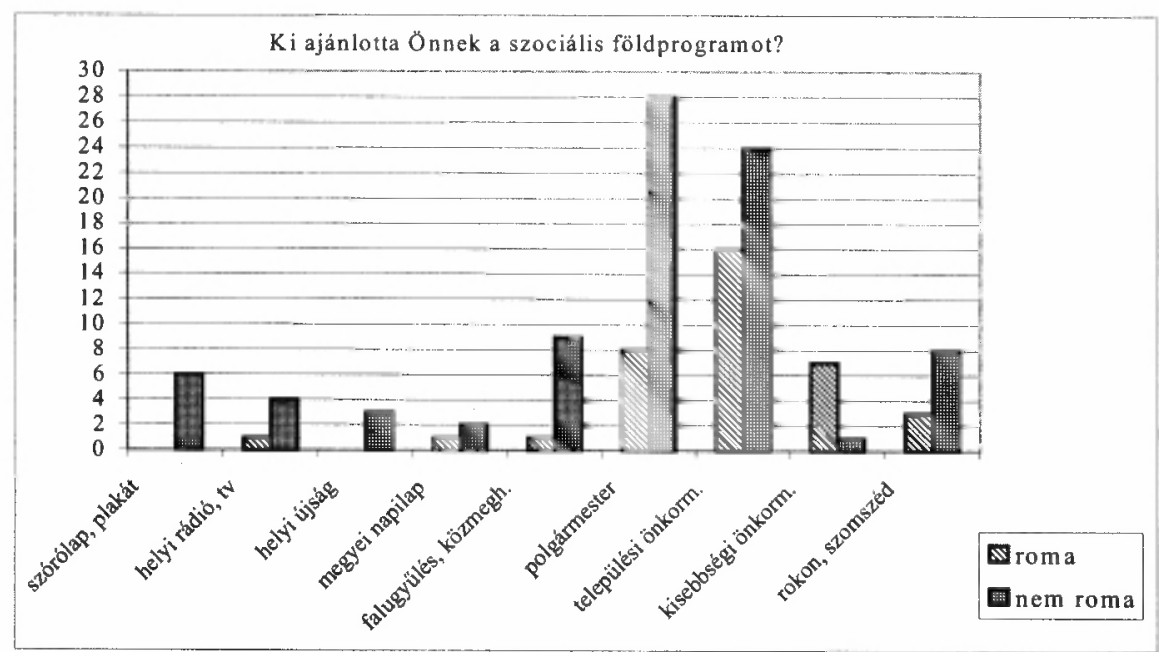

Forrás: MTA RKK ATI Szolnoki Társadalomkutató Csoport 1999. 
A program erőssége, előnye a Békés megyei megkérdezettek körében a természetbeli hatások (,több jószágot tudunk tartani, jól jön a takarmány, megtermeltük az alapvető élelmiszereket"), a vizsgálat másik két megyéjében pedig a pénzpótlás. A korábban hipotézisként megfogalmazott túlélési és hátrányos helyzetből történő kivezetési programként egyaránt használható" gondolatot igazolja, hogy a teljes minta csaknem fele jövedelempótlékként tartja fontosnak a szociális földprogram projektet. A pénzpótlás szerepe a közös háztartásban élök számának növekedésével erősödik. Minden tizedik megkérdezett a program takarmánypótló szerepét emeli ki, míg szintén minden tizedik válaszoló egyfajta „tüzoltó” szerepet (,nincs más”) tart fontosnak. Ez egyértelmüen arra utal, hogy a részt vevő családok bevételeikkel föleg a fogyasztásukban megjelenő hiányokat igyekeztek inkább pótolni.

\section{A földprogram lehetséges nyertesei}

Az innováció szempontjából meghatározónak minősíthető tervezést tükröző racionális cselekvés a szociális földprogram résztvevöi körében is felfedezhetö. Ide soroljuk a „saját termelőeszköz vásárlása”, a „rendszeres munka keresése”, a „részvétel átképzésen”, valamint a „vállalkozás indítása” és a „saját földön gazdálkodni" választípusokat.

Az elsődlegesen jelölt tervek egyrészt a racionális cselekvésre, a vélelmezhetöen nagyobb jövedelem szerzésére (,,rendszeres munka, részvétel átképzésen, vállalkozás, saját földön gazdálkodás"), másrészt tüneti cselekvésre, kezelésre, a nem tervezhető jövedelemre („szociális segély, napszám”), valamint a bizonytalanság, a kilátástalanság érzetére, a jövőképhiányra (,majdcsak lesz valahogy”) vonatkoznak (4. ábra).

\section{4. ÁBRA}

Innovációs stratégiák a földprogramos tapasztalatok birtokában (Innovation Strategies with the Results of Land Programmes)

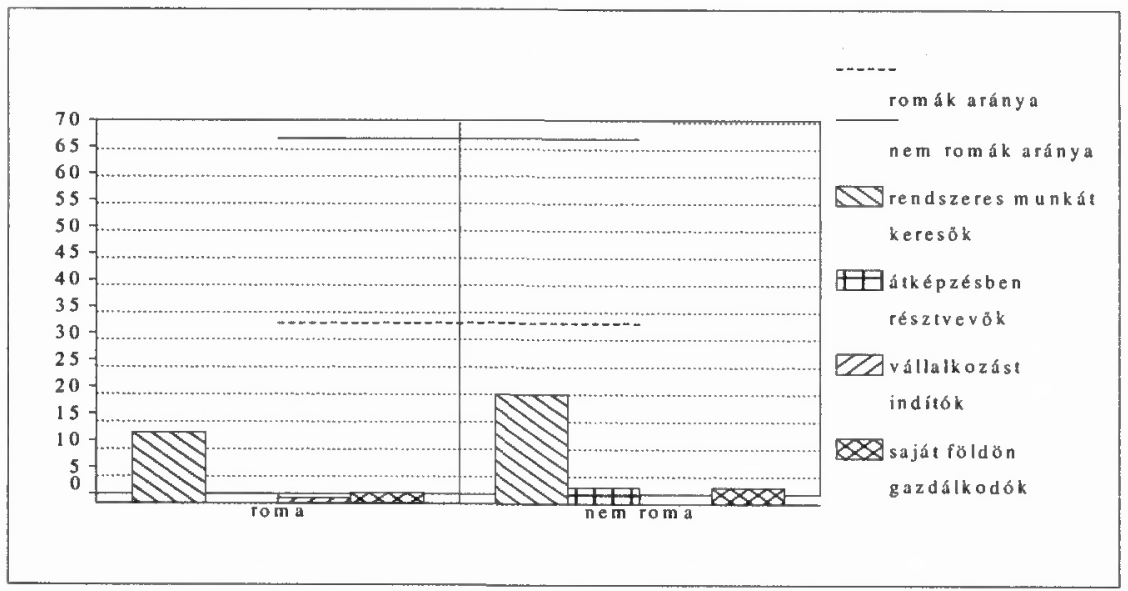

Forrás: MTA RKK ATI Szolnoki Társadalomkutató Csoport 1999. 
A kiemelkedési stratégiák közül a rendszeres munkát vállalók egyharmad-egyharmad arányban Hajú́-Biharban, valamint Jász-Nagykun-Szolnok megyében élnek. Az átképzést kizárólag ez utóbbi megyében élők vállalnák. Vállalkozást egy békési megkérdezett indítana, és a Viharsarok mellett a hajdúsági alminta kis része is elkezdené saját földje művelését. E két megyéből származnak azok a megkérdezettek is, akik saját termelöeszközt is vásárolnának.

Kor alapján nem lehet dominánsan innovatív csoportot felállítani. Az átképzést vállalók aránya három korcsoport között oszlik meg. A rendszeres munka keresésében és a saját földön történő gazdálkodásban a 41-50 évesek tekinthetök elsőnek, bár közülük kerül ki a legtöbb bizonytalan is, mert a „majdcsak lesz valahogy” válasz aránya közel $40 \%$.

A 18-24 éves alminta körében a rendszeres munka, a vállalkozás és a saját földi gazdálkodás kiemelten fontos. A nemek között nincs érzékelhetö különbség az innovatív elemekben. Átképzésre inkább a nők jelentkeznének, vállalkozni inkább a férfiak szeretnének. A megkapaszkodási elképzelésekről az identifikációs változó esetében az mondható el, hogy saját termelési eszközt - feltehetően tőke hiányában - a roma megkérdezettek egyáltalán nem vásárolnának.

Az innovációs dimenziókat folytatva fontos hangsúlyozni, hogy a háztartások létszámának növekedésével nő a ,majdcsak lesz valahogy” választípus aránya.

Az állandó munkaviszonyt a hetvenes években kezdő megkérdezetteink közül kerülnek ki leginkább a rendszeres munkát keresők. A fenti innovációs elemek alkalmazói az elmúlt 18 évben mezỏgazdasági, ipari, épitőipari munkahelyeken dolgoztak. A munka világának szocializációs tartalékai szempontjából fontos, hogy a saját termelőeszközöket vásárlóknak van már földjük, és tartanak otthon haszonállatot (sertés, baromfi), közülük kerül ki a rendszeres munkát keresők többsége.

Érdemes említést tenni arról is, hogy a saját termelési eszközt vásárlók pénzjövedelemmel kerültek ki a programból. A rendszeres munka, a vállalkozás, az átképzés, valamint az önálló gazdálkodói létet tervezők dominánsan természetbeli haszonnal zárták a legutóbbi mezőgazdasági termelési évet.

$\mathrm{Az}$ értékek összevetésekor látható, hogy az anyagi szempont mellett az egészség a legfontosabb a saját termelöeszköz vásárlását tervezöknek, a rendszeres munkát keresőknek a pénz a lényeg, akik viszont önálló gazdálkodásra gondolnak, mindezek mellett kiemelt helyet szánnak a magasabb rendủ preferenciáknak is.

A modernizációs (föként innovatív jellegủ) elemek vizsgálata kapcsán elmondható, hogy a megkapaszkodást segítö, egyéni stratégiák gyökere kialakulatlan. A racionális cselekvés ellen ható bizonytalanság jellemzésére a legjobb példa az, hogy a változtatni szándékozók körében (a saját termelöeszközt vásárlókra gondolunk itt) a „majdesak lesz valahogy" dimenzió az, amelyik leginkább jelen van az egyén magatartásának motivációjában. Bíztató azonban, hogy a racionális cselekvés inkább a 35 év alattiakra jellemző, a bizonytalanság, a passzivitás pedig az 51 év felettiekre. 


\section{Összegzés: Az ajtók záródnak?}

A drámai és hatalmas sebességü változások első éveitől már lassan 10 esztendő választ el bennünket. A kétezredik év küszöbén az állami szerepvállalás erősödését jelzi az, hogy a rendszerváltó évek „,tisztító viharában” elfeledett csoportok, régiók újra fontosak lettek a makrotársadalom számára. Jelen dolgozat egy szociálpolitikai projekt, a szociális földprogram adaptációs/innovációs hatásait vizsgálta három alföldi megyében. Témánkban ez a leszakadó/kapaszkodó társadalmi csoportok jövőkép-elképzelése.

A vizsgált rétegek körében az alrendszerek átalakulási trendje kb. 8-10 éve szakította meg a felemelkedést, a proletarizáció folyamatát. Láthattuk, hogy a változás kulcskategóriái (újítás, terjedés, alkalmazás) körükben még csak most vannak (újra) születöben. Láttuk, hogy mintánk többségében még nincsenek meghatározóan jelen azok az értékek, normák (ismeretek, teljesítmény, munka stb.), amelyek hosszabb távra is lehetővé tennék a bekapcsolódást a XX. század végén tapasztalható gazdasági-társadalmi modernizációs folyamatokba. A tartós kirekesztődés veszélye az lehet, hogy ,gondolkodásuk, értékviláguk hozzáidomul a társadalom peremén szokásos életmódhoz" (Csanády 1994). A társadalmi feszültségen, a deviáns viselkedés megszokott normává alakulásán túl rossz hatással van a családokra is, ahol a szegénység újratermelése, a hátrányos, deprivált helyzet tartóssá válása, az adaptációs és innovációs kêszség és hajlandóság tartós és a fiatalabb generációra is átörökített elvesztésével járhat. A folyamat megállítása a társadalom különböző alrendszereinek olyan rugalmasságát igényli/igényelné, amely a változások egyenes és mellékhatásait képes felszívni (Varga 1968).

Jelenleg az a helyzet, hogy a szociális földprogram azokon próbál segíteni, akik alól nemcsak a szocialista gazdaság kvázibiztonsága, hanem a második gazdaság biztosította kiegészitỏ anyagi biztonság is kiszaladt (Sági-Kolosi 1996). Óvatosságra int az, hogy mindez megtörténhet még egyszer (lásd pl. a sarkadi földprogram problematikusságát). A gazdálkodási biztonság, a pénzügyi tervezhetőség feltétele a sikeres programnak. Ezért érdemes idézni még Esztergár Lajos kezdeményezését, aki - mivel a szatmári ínségenyhítő szövetkezet ,a szociális szempontok mellett gazdasági-pénzügyi feladatot is betölt" - indítványozza azt, hogy a szövetkezet kerüljön a Pénzintézeti Központ ellenőrzése alá (Esztergár 1941). A múködtetői (szervezeti) modernizációhoz tartozik még a nagyobb haszonnal kecsegtető kultúrák termesztése is. Ezt azonban a jelenlegi (technikai és ismeretekbeli) háttérrel nehéz elkezdeni (lásd még: Baukó-Gurczó-Márton 1997). Segíteni kell a földprogramon belüli ismeretátadó összejövetelek, önsegitő csoportok kialakulását, sikeres programok bemutatását (adaptációs funkció erösítése). Véleményünk szerint önkormányzati felelősség az is, hogy a nagyobb földterülettel rendelkezök ne kerüljenek be a szociális földprogram célcsoportjai közé.

A mezőgazdasági válság sújtotta rurális kistérségek hagyományos elmaradottsága a centrum területektől a rendszerváltást követöen tovább fokozódott, felerösödött. 
A hagyományosan jól bevált, a piaci ingadozásoktól szinte független önellátó termelés - a szociális földprogram müködésének a csapdáját is ebben a tényezőben látjuk - jellegénél fogva alkalmatlan jelentősebb tőke generálására. A veszély a jelenlegi helyzetben a gazdaság archaizálódásán túl a helyi társadalom mentális és morális ,pusztulásában” van. Ebben a társadalmi folyamatban van óriási jelentősége a szociális földprogramnak, amely megkísérli a munka világán keresztül visszaintegrálni a jelentősen leszakadottakat, feltárva előttük a maguk számára lehetséges, egyéni utakat.

A szociális földprogram résztvevői munkaerö-piaci esélyének növelését a képzettségi szint emelésével látjuk megvalósithatónak. Ennek klasszikus, rövidebb időt igénylő módja az átképzések, illetve más felnőttképzési lehetőségek szélesítése. A felnövö, hátrányos helyzetủ generáció helyzetét azonban az javítaná, ha a középiskolai képzést mindenki számára kötelezővé tennék (Kertesi 1995). Ezzel, bár valószínű, hogy a fenti állami norma hatékonyságának betartása korlátokba ütközne, javulhatna a kulturális töke megszerzésének esélyegyenlösége.

Összegezve a három megyében végzett kutatást, a szociális földprogram megfelel annak a célnak, hogy a kvalifikálatlan rétegek számára újra szocializációs keretet nyújtson a munka világába. Megerősítve néhány hipotézist a program adaptív eredményei közé sorolhatjuk azt, hogy megerösít készségeket, motivációkat, növelve az esélyt az elönyösebb helyzetbe jutásra, valamint kihasználatlan emberi, tárgyi és természeti eröforrások kerülnek bevonásra a szociális rendszerbe, egy általános értékteremtő folyamatba. Azonban az innováció tartósságához, az ajtók nyitva maradásához komplex háttér - a program és az egyéni szocializáció teljesebb harmonizációja, a kockázatra, a választásra való képesség, a saját sors ellenőrizhetőségének élménye, mint az információs társadalomba való bekapcsolódás alapfeltétele is (Csepeli 1997) - szükséges.

\section{Jegyzetek}

${ }^{1}$ Az egy före jutó GDP alapján az ország megyéi közül Békés a 12, Hajdú-Bihar a 10., Jász-NagykunSzolnok a 13. volt 1996-ban (Farkasházi 1998).

${ }^{2}$ Szociális altruista szővetkezete „hitelt nyújt minden ínséges és arra rászoruló egyénnek azért, hogy gazdaságilag megerősödjék, a gazdasági elesettségből kikerüljön és ơnálló egzisztenciává alakuljon. Fontos még az, hogy a juttatásoknak az egyéni szükségletekhez kell igazodni (fokozatok: kecske, $\Rightarrow$ liba, $\Rightarrow$ naposcsibe, $\Rightarrow$ sertés, $\Rightarrow$ méhkaptár és házjuttatás), és ha ,,az elesett nem rendelkezik a szükséges erkőlcsi és ismeretbeli kellékekkel, a segítésnek az ismeretek nyújtásával és a helyes gazdálkodásra való tanítással egyuitt kell haladnia" (Esztergár 1941).

${ }^{3}$ A hipotézis nem igazolódott. A problémacsokorból kiderủl, hogy a szociális földprogram kapcsán a terméslopások gondja a megkérdezettek $23 \%$-át zavarja.

${ }^{4}$ Az életvilág a mindennapi élet azon elemeit jelenti, amelyet a társadalomban éb személy adottnak vesz. Az egyénnek a társadalomban való eligazodását, tevékenységét segíti az, hogy az életvilágot ismeri, és adottnak veszi (Andorka 1997).

${ }^{5}$ A Jász-Nagykun-Szolnok megyében élók és videóval rendelkezők körében két és félszer többen jeleztek vissza racionális cselekvést (a terv változó - „,rendszeres munka, részvétel átképzésen, vállalkozás, saját fơldoön gazdálkodás, szociális segély, napszám" - összevonåsából elnevezett kategória), mint a passziv, bizonytalanságot tükrözö, ,majdcsak lesz valahogy” magatartástípust. 
6

A romák legmagasabb iskolai végzettsége: $1-7$ osztály $33 \%, 8$ osztály $46 \%$, szakmunkásképz̋ $11 \%$, középiskola $2 \%$, diploma $0,24 \%$. A nem romák hasonló adatai: $1-7$ osztály $11 \%, 8$ osztály $36 \%$, szakmunkásképzö $20 \%$, középiskola $24 \%$, diploma $9 \%$.

${ }^{7}$ A roma életvitelünek minösítettek körében az országos munkanélküliségi ráta $35,8 \%$, a nem roma népességnél 11,2\% (Gyorsjelentés... 1996).

\section{Irodalom}

Andorka R. (1997) Bevezetés a szociológiába. Budapest, Osiris Kiadó.

Baukó T.-Gurzó I.-Márton J. (1998) A földhasználat és a térségfejlesztés néhány aspektusa Bẹ́kés megyében I. - Comitatus. 1. 25-28. o.

Csanády A. (1994) Az átalakulás határai. Törésvonalak és értékválasztások. - Balogh I. (szerk.), Budapest, MTA Politikai Tudományok Intézete. 305-319. o.

Csepeli Gy. (1997) Szociálpszichológia. Budapest, Osiris.

Diebel A. (1996) A munkanélkuiliek legveszélyeztetettebb rétegének, a tartósan munkanélkülieknek jellemzése (egy debreceni kérdöives felmérés alapján), különös tekintettel külsö és belsö családi kapcsolatrendszerük alakulására ebben a kritikus élethelyzetben. Kézirat. Debrecen, MTA RKK.

Esztergár L. (1941) Jelentés Keresztes-Fischer Ferenc M. Királyi belügyminiszternek a Szatmár vármegyei inségenyhitô tevékenységrōl. Pécs.

Farkasházi L.-né (1998) A bruttó hazai termék területi megoszlása. - Területi statisztika. január. 9. o:

Gyorsjelentés a szegénységröl. (1996) Budapest, Szociális Szakmai Szövetség.

Kemény I.-Havas G. (1996) Cigánynak lenni. - Társadalmi Riport. 352-380. o.

Kertesi G. (1995) Cigány gyermekek, cigány felnöttek a munkaeröpiacon. - Közgazdasági Szemle. 1. 50. o.

Kolosi T.-Sági M. (1996) Rendszervăltás és társadalom-szerkezet. - Társadalmi Riport. 149-197. o.

Kornai J. (1993) A szocialista rendszer. Budapest, HVG Kiadó. 237-243. o.

Magyarország Vidékfejlesztési Koncepciója (1997) Budapest, Agrárgazdasági Kutató és Informatikai Intézet.

Mezőgazdasági programok romáknak. (1997)-HVG. november 15.

Országos Terïletfejlesztési Koncepció (1997) Budapest.

Serafin J. (1997) Szociális földprogram kialakitása, müködtetése a településeken. Kézirat. Budapest.

S. Nagy K. (1997) Fogyasztás és lakáskultúra Magyarországon. - Replika. 26. 47-53. o.

Standing, G. (1993) Szerkezetátalakítás az igazságos elosztásért Kelet-Európában. - Esély. 1. 3-22. o.

Szalai J. (1998) A kényszerasszimiláció zsákutcája. - Népszabadság. február 14. 19. o.

Szoboszlai Zs. (1999) A szociális földprogram hatékonysága. - Esếly. 1. 27. o.

Varga K. (1968) Modernizáció és tömegkommunikáció. Budapest, Tömegkommunikációs Kutatóközpont.

\section{THE MODERNISATION ENDEAVOUR OF CERTAIN SOCIAL DISADVANTAGED GROUPS}

\section{TIBOR SZARVÁK}

In the last decade of the XX century the Hungarian society is in for a cogent possibility since it may participate in a closed European integration process. The complete research of the adaptation and innovation strategies of the society is indispensable in order that the modernisation of the country hasn't got chapters characterised by delay.

This study tries to find the closing up and development (adaptation-innovation) chances of the population living in the rural areas far from the globalisation process could characterised by objective-relative deprivation (low income, low educational level, poorly equipped or unhealthy housing) and the lack of different sets of 
innovation. It covers three counties (Békés, Hajdú-Bihar, Jász-Nagykun-Szolnok) which are characterised by different dimensions of regional disparities.

The sample of the analysis was the social land program initiated by the Ministry of Welfare 6 years ago and the families (and for background the settlements) involved the program. The analysis of the regional influences obtain a picture about the development of the employment status of the last 18 years, the sociological relations of families and the circumstances of life and the ambition of those people utilised the above mentioned transfers. 